\title{
JNPH
}

Volume 5 No. 2 (Desember 2017)

(C) The Author(s) 2017

\section{APLIKASI TEORI KONSEP KEPERAWATAN JEAN WATSON TERHADAP ANAK "S" DENGAN HIDROCEFALUS DI KELURAHAN SUMUR DEWA KECAMATAN SELEBAR WILAYAH KERJA PUSKESMAS BASUKI RAHMAD KOTA BENGKULU}

\author{
APPLICATION OF THE THEORY OF JEAN WATSON CONCEPT WITH TO CHILD \\ "S" WITH HIDROCEFALUS IN SUMUR DEWA SUBURBS OF SELEBAR DISTRICT \\ IN WORKING AREA OF BASUKI RAHMAD PUBLIC HEALTH CENTER \\ BENGKULU CITY
}

\author{
SURYANTI \\ UPTD PUSKESMAS BASUKI RAHMAT KOTA BENGKULU \\ Email: Ssabil345@gmail.com
}

\begin{abstract}
ABSTRAK
Dampak dari penyakit hidrosefalus itu sendiri berpengaruh terhadap sensotik dan motorik serta mengalami perawatan khusus seumur hidup. Asuhan keperawatan yang dilakukan sangatlah berpengaruh terhadap pasien tersebut, Salah satu teori model keperawatan yang dapat diaplikasikan pada pasien dengan hidrosepalus adalah teory of Human Caring, yang dikemukakan oleh Jean Watson berpendapat, keperawatan fokusnya lebih pada promosi kesehatan, pencegahan penyakit, merawat yang sakit, dan pemulihan keadaan fisik. penulis mengurai laporan kasus/asuhan keperawatan yang diberikan pada An. S dengan mengaplikasikan teori model Jean Watson dengan menggunakan metode proses keperawatan yang meliputi pengkajian, diagnose keperawatan, perencanaan, implementasi dan evaluasi asuhan keperawatan ini. Teori Jean Watson fokus pada cara merawat keluarga yang sakit, dimana nantinya orang tua mampu melakukan perawatan pada anak-anaknya yang sakit Hydrocephalus dengan tujuan untuk peningkatan kesehatan. Keunggulan teori ini dalam berkaitan dengan kasus Hydrocephalus adalah orang tua An "S" faktor penyebab Hydrocephalus yaitu bisa karena kista araknoid, anomalia pembuluh darah, infeksi, neoplasma, dan perdarahan.
\end{abstract}

Kata Kunci: hidrocefalus, teori Jean Watson

\begin{abstract}
The impact of hydrocephalus disease itself affects the sensory and motor and also undergoes special treatment for life. Nursing care performed is very influential on these patients, one of them by providing moral and social support for families of patients to be patient and steadfast care and treatment. One theory of nursing model that can be applied to patients with hydrocephalus is the theory of human caring, suggested by Jean Watson, that nursing focuses more on health promotion, disease prevention, treating the sick, and restoring the physical state. the authors parse the case report / nursing care given to An. S by applying the model theory of Jean Watson using the method of nursing process that includes assessment, nursing diagnosis, planning, implementation and evaluation of this nursing care. Jean Watson's theory focuses on
\end{abstract}


how to care for a sick family, where the parents will be able to take care of their sick child Hydrocephalus for the purpose of health promotion. The superiority of this theory in relation to the case of Hydrocephalus is the parent An "S" factor that causes Hydrocephalus can be due to Araknoid Cyst, Anomalia blood vessels, infections, neoplasms, and bleeding.

Keywords: hidrocefalus, Jean Watson theory

\section{PENDAHULUAN}

Sehat adalah sebuah investasi, asset, dan harta yang paling berharga bagi setiap individu. Health is not everything but, without health everything is nothing, menjadi sebuah penyempurna jika sehat merupakan starting point untuk pembangunan. Menurut, WHO, sehat bukan hanya keadaan yang bebas dari penyakit melainkan juga keadaan yang sempurna baik fisik, mental maupun sosial. (Sudomo, 2014).

Hidrosefalus berasal dari kata hidro yang berarti air dan chepalon yang berarti kepala. Hidrosefalus merupakan penumpukan cairan serebrospinal secara aktif yang menyebabkan dilatasi system ventrikel otak dimana terjadi akumulasi cairan yang berlebihan pada satu atau lebih ventrikel atau ruang subarachnoid. Kita mengenal "Hydrocephalus" sebagai suatu kelainan yang biasanya terjadi pada bayi, dan ditandai dengan membesarnya kepala melebihi ukuran normal. Dalam keadaan normal, tubuh memproduksi cairan otak (Cairan Serebro Spinal = CSS) dalam jumlah tertentu, untuk kemudian didistribusikan dalam ruang-ruang ventrikel otak, sampai akhirnya diserap kembali. Sedangkan pada orang dewasa, tulang tengkorak tidak lagi mampu melebar. Akibatnya berapapun banyaknya CSS yang tertumpuk, takkan mampu menambah besar diameter kepala (Nanda, 2013).

Hidrosefalus merupakan penimbunan cairan serebrospinalis dalam ventrikel otak, sehingga kepala menjadi besar. Jumlah cairan bisa mencapai 1,5 liter bahkan ada sampai 5 liter, sehingga tekanan intrakranial sangat tinggi. Hidrosefalus sering di jumpai sebagai kelainan konginetal namun bisa pula oleh sebab postnatal. Angka kejadian hidrosefalus kira-kira $30 \%$ yang di temui sejak lahir, dan $50 \%$ pada 3 bulan pertama. Frekuensi hidrosefalus ini utero 2:2000 bayi, dan kirakira $12 \%$ dari semua kelainan konginetal. Hidrosefalus sering menyebabkan distosia persalinan. Dan setelah lahir dan tetap hidup akan menjadi masalah pediatri dan sosial. Pasien hidrosefalus merupakan pasien yang sangat menderita dan memerlukan perawatan khusus dan benar karena ada kerusakan saraf yang menimbulkan kelainan neurologis berupa gangguan kesadaran sampai pada gangguan pusat vital dan resiko terjadi dekubitus (Cathlyn, 2013).

Data WHO tentang Hidrosefalus di Amerika Serikat insidens hidrosefalus congenital adalah 1 dari 1000 kelahiran dimana insiden hydrosefalus dapatan tidak diketahui secara pasti. Internasional insiden dari hidrosefalus dapatan tidak diketahui. Sekitar 100.000 pemasangan shunting dilakukan setiap tahun pada Negara-negara berkembang tetapi sedikit infromasi yang tersedia untuk negara lainnya. Hidrosefalus adalah salah satu dari kelainan tersering yang menimpa lebih dari 10.000 bayi setiap tahun, dan lebih dari 50\% kasus hidrosefalus adalah hidrosefalus congenital (Maliawan, 2014).

Menurut penelitian WHO untuk wilayah ASEAN jumlah penderita Hidrosefalus di beberapa negara adalah sebagai berikut, di Singapura pada anak 0-9 th : 0,5\%, Malaysia : anak 5-12 th $15 \%$, India anak $2-4$ th $4 \%$, di Indonesia berdasarkan penelitian dari Fakultas Ilmu Kedokteran Universitas Indonesia terdapat 3\% (who, 2013).

Berdasarkan statistic Medical Record of Indonesia, pada tahun 2014 jumlah pasien penderita hidrosefalus berjumlah 115 orang. Lalu pada tahun 2015 dari bulan januari sampai bulan mei jumlah pasien penderita hidrosefalus adalah 210 orang. Pada tahun 2016 meningkat menjadi 311 orang. Sementara di provinsi Bengkulu pada Rumah Sakit M. Yunus pada tahun 2015 ada 9 orang 
penderita hidrosefalus, dan pada tahun 2016 ada 13 orang penderita hidrosefalus, dan 10 diantaranya tidak bisa diselamatkan dan 3 orang lainnya masih dalam perawatan rujukan di Jakarta (Rikesdas, 2017).

Dilaporkan sekitar 25\%-40\% malfungsi shunt terjadi pada 1 tahun pertama pemasangan (Weprin, 2002). Dari penelitian yang lain didapatkan data bahwa sekitar 30\%$40 \%$ malfungsi shunt terjadi akibat proses mekanis atau proses infeksi pada tahun pertama pemasangan, dan sekitar 15\% kegagalan terjadi pada tahun kedua. Setelah tahun kedua, tingkat kegagalan turun menjadi 1\%-7\%. Hal ini menyebabkan naiknya tingkat mortalitas pasien hidrosefalus menjadi $0,1 \%$. Mortalitas terkait malfungsi shunt dijumpai sekitar $1 \%-4 \%$ dari total populasi (Piatt, 2013).

Dampak dari penyakit hidrosefalus itu sendiri berpengaruh terhadap sensotik dan motorik serta mengalami perawatan khusus seumur hidup. Asuhan keperawatan yang dilakukan sangatlah berpengaruh terhadap pasien tersebut, salah satunya dengan memberi dukungan moral dan sosial bagi keluarga penderita agar sabar serta tabah merawat dan menjalani pengobatan. Aktivitas keperawatan bersifat "caring character" yang berfokus pada peningkatan penyembuhan pasien dan melakukan penyuluhan, perawatan tindak lanjut dan rujukan yang penting untuk penyembuhan dan rehabilitasi serta pemulangan (Baradero et al, 2013).

Adapun tujuan dari praktek keperawatan adalah untuk meningkatkan kemampuan keluarga dalam mengatasi masalah kesehatannya secara mandiri. Oleh karena itu, untuk dapat tercapainya tujuan praktek keperawatan secara optimal dan berkualitas, maka perlu mengembangkan ilmu dan praktek keperawatan salah satunya melalui penerapan model konseptual (Padila, 2012).

Teori keperawatan digunakan untuk menyusun suatu model konsep dalam keperawatan, sehingga model keperawatan tersebut mengandung arti aplikasi dari struktur keperawatan itu sendiri yang memungkinkan perawat untuk mengaplikasikan ilmu yang pernah didapat ditempat mereka bekerja dalam batas kewenangan sebagai seorang perawat.

Adanya tujuan praktek yang ingin dicapai dalam memberikan pelayanan ataupun asuhan keperawatan terhadap kebutuhan semua pasien, serta adanya pengetahuan dan ketrampilan yang dibutuhkan oleh perawat dalam mencapai tujuan yang ditetapkan sesuai kebutuhan pasien (Rianti, 2012).

Salah satu teori model keperawatan yang dapat diaplikasikan pada pasien dengan hidrosepalus adalah teory of Human Caring, yang dikemukakan oleh Jean Watson berpendapat, keperawatan fokusnya lebih pada promosi kesehatan, pencegahan penyakit, merawat yang sakit, dan pemulihan keadaan fisik. Keperawatan pada promosi kesehatan awalnya sama dengan mengobati penyakit. Dia melihat keperawatan dapat bergerak dari dua area, yaitu: masalah penanganan stres dan penanganan konflik.

Hal ini dapat menunjang tersedianya perawatan kesehatan yang holistik, yang dia percayai dapat menjadi pusat dari praktik keperawatan. Salah satu asumsi Watson mengatakan bahwa kondisi sosial, moral, dan ilmu pengetahuan sangat berkontribusi terhadap kondisi kesehatan manusia dan masyarakat, sehingga perawat perlu berkomitmen terhadap pemberian asuhan kesehatan yang ideal melalui kajian teori, praktek, dan riset keperawatan (Wijaksono, 2013).

\section{METODE PENELITIAN}

Dalam penelitian ini penulis akan mengurai laporan kasus/asuhan keperawatan yang diberikan pada An. S dengan mengaplikasikan teori model Jean Watson yang dilaksanakan selama 1 minggu pada tanggal 20-28 Mei 2017 dengan menggunakan metode proses keperawatan yang meliputi pengkajian, diagnose keperawatan, perencanaan, implementasi dan evaluasi asuhan keperawatan ini. 


\section{HASIL PENELITIAN}

Pada bab ini akan dibahas mengenai pelaksanaan asuhan keperawatan pada An.S dengan penyakit Hydrochepalus di Jl Padat Karya Rt.01 Kel. Sumur Dewa Kota Bengkulu. Dilakukan melalui beberapa proses keperawatan yang terdiri dari pengkajian, analisis data, diagnosa, intervensi, implementasi, dan evaluasi.

\section{Tahap Pengkajian}

Penerapan pengkajian dengan menggunakan Teori Human caring Jean teori Jean Watson ini memahami bahwa manusia memiliki empat cabang kebutuhan manusia yang saling berhubungan di antaranya kebutuhan dasar biofisikal (kebutuhan untuk hidup) yang meliputi kebutuhan makanan dan cairan, kebutuhan eliminasi dan kebutuhan ventilasi, kebutuhan psikofisikal (kebutuhan fungsional) yang meliputi kebutuhan aktivitas dan istirahat, kebutuhan seksual, kebutuhan psikososial (kebutuhan untuk integrasi) yang meliputi kebutuhan untuk berprestasi, kebutuhan organisasi, dan kebutuhan intra dan interpersonal (kebutuhan untuk pengembangan) yaitu kebutuhan aktualisasi diri.

Pada tahap ini Penulis melakukan pengkajian pada An $S$ melalui proses wawancara kepada orang tuanya. Hasil pengkajian didapatkan data yaitu : Nama Pasien An "S", umur 7 tahun, alamat Jl Padat Karya Rt 01 Kel. Sumur Dewa Kota Bengkulu, Sekolah Dasar, Ras Sumatera, Agama Islam, TB 120,80 cm dan BB $22 \mathrm{~kg}$. Pada pengkajian ditemukan data subjektif orang tua An "S" bahwa anaknya sering mengeluh mual bila terlalu banyak makan dan minum, jika terlalu lama belajar disekolah, anaknya sering mengeluh sakit kepala, anaknya sering juga mengeluh mual jika terlalu banyak duduk RR : $25 \times$ menit.

\section{Tahap Perumusan Diagnosa}

Pada kasus keperawatan yang dialami
An. S, setelah dilakukan pengkajian keperawatan meliputi 4 bagian kebutuhan dasar manusia yang terdiri dari kebutuhan dasar biofisikal (kebutuhan untuk hidup) yang meliputi kebutuhan makanan dan cairan, kebutuhan eliminasi dan kebutuhan ventilasi, kebutuhan psikofisikal (kebutuhan fungsional) yang meliputi kebutuhan aktivitas dan istirahat, kebutuhan seksual, kebutuhan psikososial (kebutuhan untuk integrasi) yang meliputi kebutuhan untuk berprestasi, kebutuhan organisasi, dan kebutuhan intra dan interpersonal (kebutuhan untuk pengembangan) yaitu kebutuhan aktualisasi diri

Dari hasil data pengkajian diatas maka dirumuskan diagnosa keperawatan yaitu resiko yang terjadinya komplikasi penyakit berhubungan dengan jika tidak patuhnya An "S" dalam menjalani perawatan untuk Hydrocephalus dan aktifitas fisik yang terlalu banyak. Diagnosa keperawatan yang diangkat adalah Resiko gangguan Biophisical needs berhubungan dengan Komplikasi Post Operasi hidrosefalus.

\section{Tahap Intervensi}

Intervensi keperawatan menurut teori Jean watson adalah Perencanaan membantu untuk menentukan bagaimana variablevariabel akan diteliti atau diukur, meliputi suatu pendekatan konseptual atau design untuk memecahan masalah yang mengacu pada asuhan keperawatan serta meliputi penentuan data apa yang akan dikumpulkan dan pada siapa dan bagaimana data akan dikumpulkan.

Rencana asuhan keperawatan kepada An "S" dengan diagnosa Hydrocephalus untuk memperhatikan aktifitas anak dan pola makan yang tidak berlebihan dengan tujuan setelah tindakan keperawatan $4 \times 24$ jam resiko komplikasi Hydrocephalus teratasi dan kriteria hasil An "S" bisa mengurangi aktifitas bermain ataupun kegiatan lain yang terlalu banyak, orang tua An "S" mampu memberikan keperawatan pada An "S" dengan penyakit Hydrocephalus. Dengan 
intervensinya sebagai berikut : beri dorongan sikap penerima terhadap anak (misalnya di peluk, berbicara dan menyenangkan anak), Bantu orang tua untuk ikut merawat anaknya, libatkan orang tua sebanyak mungkin, jelaskan setiap prosedur perawatan dan pengobatan.

Dorong sikap positif dari orang tua, beri perjelaskan sikap negative, diskusikan sikap indentifikasi frustasi ajarkan cara penyelesaiannya dengan koping yang baru. Bantu orang tua untuk dapat menerima knyataan tentang perubahan dan perkembangan anak, yakinkan orang tua bahwa anak membutuhkan kasih sayang dan keamanannya, demonstrasikan perawatan yang di perlukan pasien kepada keluarga (bagaimana mengecek fungsi shunt, posisi anak), berikan kesempatan untuk mengulang, dan beri penjelasan tentang pengobatan, sampai dengan perawatan selang shunt.

\section{PEMBAHASAN}

\section{Tahap Implementasi}

Pada tahapan terakhir yaitu implementasi keperawatan, menurut teori watson Implementasi keperawatan yaitu melaksanankan tindakan keperawatan sesuai dengan rencana keperawatan yang akan dilakukan. Implementasi yang telah dilakukan untuk diagonsa keperawatan: Resiko terjadinya komplikasi Hydrocephalus berhubungan dengan perawatan luka kulit terhadap kontaminsai infeksi dan pemantauan fungsi alat shunt yang dipasang serta resiko infeksi alat shunt dan ketidak tahuan orang tua dalam penanganan pengobatan Hydrocephalus adalah Beri dorongan sikap penerima terhadap anak ( misalnya di peluk, berbicara dan menyenangkan anak), Bantu orang tua untuk ikut merawat anaknya, libatkan orang tua sebanyak mungkin, Jelaskan setiap prosedur perawatan dan pengobatan, Dorong sikap positif dari orang tua, beri perjelaskan sikap negative.

Implementasi yang telah dilakukan diagnosa keperawatan Hydrocephalus adalah
Keluarga memahami dan memberikan respon positif kepada anaknya, Keluarga mengerti dan akan merawat anaknya dengan sepenuh hati, Keluarga memahami perawatan dan pengobatan, Keluarga memahami dan memberikan respon positif kepada anaknya dan tidak memberikan respon negative terhadap anaknya, dan Keluarga memahami dan dan mengidentifikasi masalah dan mencari solusi penyelesaian.

\section{Tahap Evaluasi}

Menurut Mareelli, 2007 evaluasi keperawatan merupakan tahap akhir dari tahap -tahap proses keperawatan untuk mengetahui apakan masalah-masalah keperawatan yang muncul pada kasus asuhan keperawatan pada pasien dengan post sirkumsisi teratasi atau tidak dan untuk membandingkan antara yang sistematik dengan yang terencana berkaitan dengan fasilitas yang tersedia. Berdasarkan hal tersebut penulis melakukan evaluasi keperawatan pada kasus ini, 1 diagnosa yang penulis angkat, dapat diatasi dengan baik dalam jangka waktu 4 hari, semua tujuan keperawatan yang ada di tujuan dan keriteria hasil dapat tercapai.

\section{Keefektifan aplikasi teori dalam menyelesaikan masalah yang diangkat}

Keefektifan dari teori Jean Watson pada masalah Hydorcephalus ini yaitu mengajarkan kepada pasien dan keluarga hal hal yang berkaitan dengan Hydrocephalus dan mengenalkan perawatan pada anggota keluarga yang terkena Hydrocephalus terhindar dari komplikasi dengan tentunya melaksanakan implementasi yang diberikan dengan mengacu pada pelaksanaan hidup bersih dan sehat, serta pengaturan aktifitas dan pola akan anak. Setelah dilakukan selama 5 hari semua implementasi dapat dipahami dan dilakukan sesuai dengan teori Jean Watson yang berfokus pada perawatan pasien dalam memelihara kesehatan anak dan dapat langsung diterapkam kepada pasien 
Hydrocephalus.

Model konseptual yang diangkat untuk melakukan asuhan keperawatan pada An "S" dengan Hydrocephalus ini dilakukan dengan mengaplikasikan teori Jean Watson, dimana teori ini mengarahkan tindakan pada pemeliharaan hubungan timbal balik dalam kesehatan, sehat sakit yang berkonsentrasi pada peningkatan kesehatan dalam pencegahan penyakit.

Model Jean Watson ini bentuk keperawatannya menolong klien untuk mencapai atau memelihara kesehatan dengan tenang.

Tindakan hubungan dengan proses perawatan manusia, penguasaan ilmu pengetahuan adalah utama dalam memberikan tindakan perawatan mengenai perilaku manusia dan respon manusia untuk menentukan masalah yang nyata atau potensial kebutuhan klien, menempatkan perilaku sebagai fokus asuhan keperawatan dan perhatian dimana perawat tidak perlu memahami seluruh proses penyakit, tetapi lebih berorientasi pada pemberian pendidikan kesehatan dalam upaya menciptakan perilaku yang baik dalam pencegahan penyakit. Karena itu konsep model Jean Watson perawat mengajarkan klien untuk selalu menjaga perilaku yang baik dalam mengontrol penyakit.

\section{Keunggulan aplikasi teori Jean Watson}

Seperti kita ketahui bahwa teori Jean Watson fokus pada cara merawat keluarga yang sakit, dimana nantinya orang tua mampu melakukan perawatan pada anak anaknya yang sakit Hydrocephalus dengan tujuan untuk peningkatan kesehatan. Keunggulan teori ini dalam berkaitan dengan kasus Hydrocephalus adalah orang tua An "S" faktor penyebab Hydrocephalus yaitu bisa karena Kista Araknoid, Anomalia pembuluh darah, infeksi, neoplasma, dan perdarahan.

\section{Kelemahan aplikasi teori Jean Watson}

Kelemahan teori Jean Watson ini menurut penulis adalah kurang lengkapnya poin poin dalam pengkajian yang mencakup kajian tentang pasien dengan penyakit Hydrocephalus secara spesifik karena terlihat jelas aplikasi teori keperawatan ini hanya berfokus pada perawatan pasien yang sakit sehingga penulis sedikit kesulitan untuk menentukan diagnosa keperawatan prioritas.

\section{KESIMPULAN}

Setelah penulis melakukan aplikasi teori model Jean Watson pada kasus hidrosefalus selama 4 hari perawatan, maka penulis menarik kesimpulan bahwa: Pengkajian yang dilakukan pada An. S sesuai dengan focus pengkajian Menurut Jean Watson, diagnosa yang diangkat dalam kasus yakni masalah utama resiko gangguan Resiko gangguan Biophisical needs berhubungan dengan Komplikasi Post Operasi hidrosefalus. Hasil dari pasien, tahap evaluasi dari diagnosa keperawatan yang penulis implementasikan selama 4 hari berhasil dilakukan, teori Model Jean Watson efektif di aplikasikan pada anak dengan khasus Hidrpsefalus, ditemukan kelebihan dan kekurangan Teori Model Jean Watson.

\section{SARAN}

Disarankan untuk memberikan pengetahuan dan edukasi pada ibu khususnya tentang cara perawatan pada anak post operasi hidrosefalus, sehingga ibu memiliki pengetahuan untuk merawat anaknya lebih baik, untuk mencapai peningkatan status kesehatan, dapat dijadikan sebagai salah satu bahn ajar agar memberikan gambaran tentang merawat anak dengan hidrosefalus, dengan mengaplikasikan teori model Jean Watson.

\section{DAFTAR PUSTAKA}

Ali, Zaidin. 2012. Dasar-Dasar Keperawatan Profesional. Jakarta: Widya Medika http://perawattegal.wordpress.com/2017/ 4/17/sejarah-keperawatan-islam- 
rufaidah-binti-saad/

Asmadi. 20013 Konsep Dasar Keperawatan. Jakarta: EGC http://Teori Keperawatan_ Abdellah « Elisasiregar's Blog.mht/

Closkey JC \& Bulechek. 1996. Nursing Intervention Classification. $2^{\text {nd }}$ ed. Mosby Year Book.

Eko Prasetyo. 2014. Hidrosefalus Fakultas Kedokteran Universitas Sam Ratulangi: Manado http://www.hydroassoc.org

Hasan, Rupseno, 2013, Buku Kuliah Ilmu Kesehatan Anak II, Jakarta, Bagian Ilmu Kesehatan Anak FK UI.

Hidayat, A. Aziz Alimul. 2007. Pengantar Konsep Dasar Keperawatan. Jakarta : Salemba Medika

Johnson M, dkk. 2012. Nursing Outcome Classification (NOC). Second edition. Mosby. 